
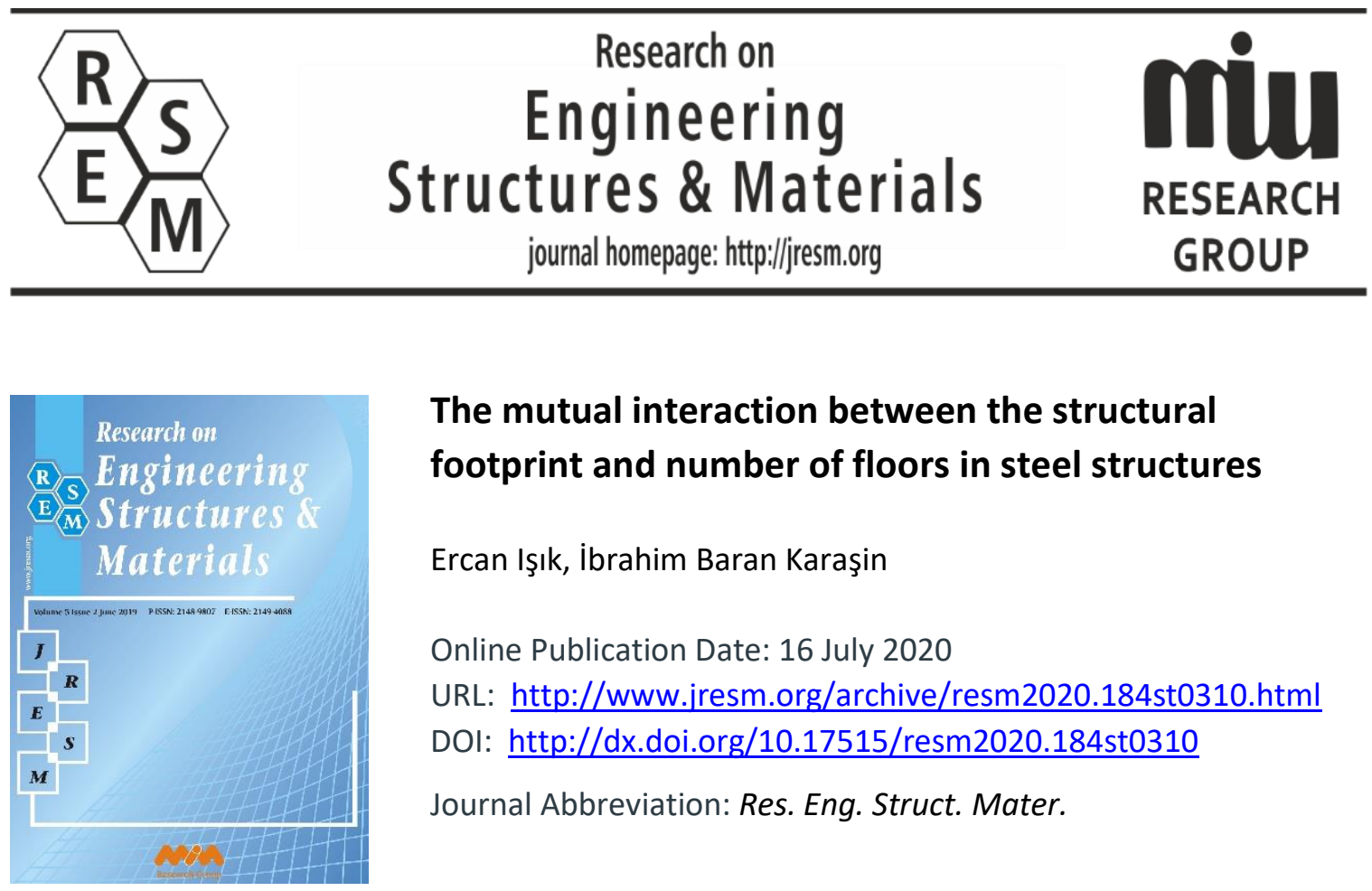

\title{
The mutual interaction between the structural footprint and number of floors in steel structures
}

Ercan Işık, İbrahim Baran Karaşin

Online Publication Date: 16 July 2020

URL: http://www.jresm.org/archive/resm2020.184st0310.html

DOI: http://dx.doi.org/10.17515/resm2020.184st0310

Journal Abbreviation: Res. Eng. Struct. Mater.

\section{To cite this article}

Işık E, Karaşin B. The mutual interaction between the structural footprint and number of floors in steel structures. Res. Eng. Struct. Mater., 2021; 7(1): 65-86.

\section{Disclaimer}

All the opinions and statements expressed in the papers are on the responsibility of author(s) and are not to be regarded as those of the journal of Research on Engineering Structures and Materials (RESM) organization or related parties. The publishers make no warranty, explicit or implied, or make any representation with respect to the contents of any article will be complete or accurate or up to date. The accuracy of any instructions, equations, or other information should be independently verified. The publisher and related parties shall not be liable for any loss, actions, claims, proceedings, demand or costs or damages whatsoever or howsoever caused arising directly or indirectly in connection with use of the information given in the journal or related means.

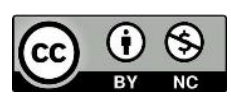

Published articles are freely available to users under the terms of Creative Commons Attribution - NonCommercial 4.0 International Public License, as currently displayed at here (the "CC BY - NC"). 


\title{
Research on Engineering Structures \& Materials \\ journal homepage: http://jresm.org
}

Research Article

\section{The mutual interaction between the structural footprint and number of floors in steel structures}

\author{
Ercan Işık1,a, İbrahim Baran Karaşin²,b,* \\ ${ }^{1}$ Bitlis Eren University, Faculty of Engineering and Architecture, Civil Engineering Dept. Bitlis Turkey. \\ ${ }^{2}$ Dicle University, Faculty of Engineering, Civil Engineering Dept. Diyarbakır- Turkey.
}

\begin{tabular}{|c|c|}
\hline Article Info & Abstract \\
\hline $\begin{array}{l}\text { Keywords: } \\
\text { Steel; } \\
\text { Footprint; } \\
\text { Number of floor; } \\
\text { Cost; } \\
\text { Pushover; } \\
\text { Material model. }\end{array}$ & $\begin{array}{l}\text { Structural dimensions and number of floors are some of the factors affecting the } \\
\text { building behaviour under the earthquake effects. In this study, the structural } \\
\text { footprint and the number of floors were selected as a variable. For this purpose, } \\
\text { a steel structure model with fixed dimensions and properties of load-bearing } \\
\text { system elements was selected. The structural footprint was selected as the first } \\
\text { variable and then five different structure models were created. The structural } \\
\text { footprint was changed by setting each axial clearance in both directions. Each } \\
\text { axial clearance was increased by } 0.5 \mathrm{~m} \text { in each structure model. Three different } \\
\text { number of floors as to be } 5,6 \text { and } 7 \text { floors were selected as the second variable. } \\
\text { Eigenvalue and pushover analyses were performed for each model and each } \\
\text { number of floors. As a result of the analyses, the target displacement values for } \\
\text { period, frequency, cumulative participation mass ratio, base shear force, } \\
\text { settlement, stiffness and degree of damage were acquired separately. As the } \\
\text { structural footprint and number of the floors increase, while the period, } \\
\text { settlement and the target displacement values increased, on the contrary, there } \\
\text { was a decrease in participation mass ratio, base shear forces and stiffness values. } \\
\text { In the study, cost comparisons of building construction were also made } \\
\text { considering the change in the total structural area and the number of floors. The } \\
\text { criterion of safety and economy was ignored due to increase both in the number } \\
\text { of floors and the footprint. This study emphasizes the importance of avoiding the } \\
\text { unnecessary structural dimensions via optimum design principles. As structural } \\
\text { footprint area and number of floors increase, period values increase, stiffness } \\
\text { and seismic capacity values decrease. As the number of floors and footprint area } \\
\text { increases, the total building area increases, so the approximate building cost has } \\
\text { also increased. }\end{array}$ \\
\hline
\end{tabular}

(C) 2021 MIM Research Group. All rights reserved.

\section{Introduction}

There are several parameters that can adversely affect the building behaviour under the vertical and horizontal loads. It is possible to gather most of these parameters under the structural characteristics. Structural characteristics are provided by the application of engineering principles in the design and evaluation of structures. Structural characteristics may positively/adversely affect the building behaviour and particularly earthquake response $[1,5]$. The total number of stories is one of the important factors determining the degree of damage caused by an earthquake. There is a direct relationship between the number of floors and earthquake damages. The increase in the amount of damage is

${ }^{*}$ Correspondingauthor: barankarasin@gmail.com

a orcid.org/0000-0001-8057-065X; b orcid.org/0000-0001-5990-1215;

DOI: http://dx.doi.org/10.17515/resm2020.184st0310

Res. Eng. Struct. Mat. Vol. 7 Iss. 1 (2021) 65-86 
unavoidable for the structures having negligent structural characteristics in the design and period [6,7].

There are three main elements in the design and evaluation of structural systems as to be load, material and dimensional conditions. The concept of dimension figures the loadbearing systems, non-load bearing systems and other structural characteristics in three dimensions. The two-way length values forming the total structural area take an important place in the concept of dimension. Dimensions, stated as width and length, can be calculated as the sum of the axial clearances forming the load-bearing system and consoles outside the axle. The total structural area was effective in all the stages of structural calculation, as well as in terms of cost. The structural area may be determined larger than adequate due to some reasons. This determination has some effects both in structural calculations and in economic terms.

There are different studies with the effect of the number of floors on the building performance, and different types of analysis have been taken into account for different parameters [8-10]. The results obtained from these studies do not overlap exactly [10]. A great number of design variables were affect to the construction costs. The most important design variables that affect the total cost of the structure; shape and complexity of buildings plan, number and height of floors and service requirements of the building [11-13]. Most of the studies to examine the relationship between them are related to reinforced concrete structures. In some of these studies, it was determined that the increase in the number of floors increased the cost of the building $[14,15]$. In some studies, they said that with the increase in the number of floors, the unit cost will decrease and then increase again, that is, a U-shaped relationship [16, 17].

Within the scope of this study, both the number of floors and the axial clearance that forms the structural footprint were selected as variables for steel structure model. Three different values were considered in terms of number of floors as to be 5, 6 and 7 floors. In terms of structural footprint, on the other hand, five different models were selected where the axial clearance values were same in both $X$ and $Y$ axis. $4 \mathrm{~m}, 4.5 \mathrm{~m}, 5 \mathrm{~m}, 5.5 \mathrm{~m}$ and $6 \mathrm{~m}$ were selected as the axial clearance values. The structural footprint of the steel structure model was changed with the changing axial clearance values. Analyses were performed by enabling the interaction between the changing number of floors and the structural footprints reciprocatively. Eigenvalue analyses were performed by using the steel structure models with five different structural footprints for each number of floors. The target displacement values for base shear force, settlement, stiffness and degree of damage were acquired separately for each structural model by using pushover analysis. All results were compared for both structural footprints and number of floors change. Cost accounts were carried out in order to reveal the relationship of these two variables between the building construction costs. Proposals were made after evaluating the analysis results.

In the first part of the study, information was given about the types of analysis used in the selected building constructions. The structural characteristics of the selected steel structure were presented in the next step. Information was provided about the different building models considered in the study and the results were compared. In the final part of the study, the way how the construction costs were calculated was explained, and cost values were compared for all models used.

Both structural analysis and economic comparisons in reinforced concrete structures are available in the literature. No such publication was found in steel structures. Two different parameters selected within the scope of the study are both important in terms of building cost and earthquake effects. All conceivable values related to the variables considered in 
the study were obtained. Both the behaviour under the effects of earthquake and cost calculations was obtained in detail for steel structures. This shows that, this study can be used in both the scientific and construction sectors.

\section{Methodology}

Firstly, eigenvalue analyses were performed to the structural models for each variable used in this study. Mode shapes and natural frequency for any structure can be acquired by eigenvalue analysis. Material properties always remain constant via calculation. Briefly, it can be considered as a sheer elastic structural analysis. The section can be symbolized with material sectional properties such as torsional constant, moment of inertia, modulus of elasticity and modulus of stiffness. Eigenvalue analysis was used to obtain the period, frequency, participation modal factors, effective modal masses and their percentage values related to the structure [18-20]. Another analysis used for all steel structure models selected within the scope of the study was pushover analysis. Pushover analysis is widely used for the structural performances in a potential earthquake. Pushover analysis captures the nonlinear structural behaviour effectively and hence can trace the structural behaviour progressively up to failure. Pushover analysis can provide the most effective measure of global structural behaviour in terms of base shear capacity and displacement ductility of the structure. A capacity curve obtained via pushover analysis represents the relationship between the base shear force and the displacement of the roof. The base shear was normalized by structure seismic weight, while the roof level displacement was normalized by building height to represent the shear strength coefficient and roof displacement drift, respectively [21-23]. A typical example of idealised capacity curve is shown in Figure 1.

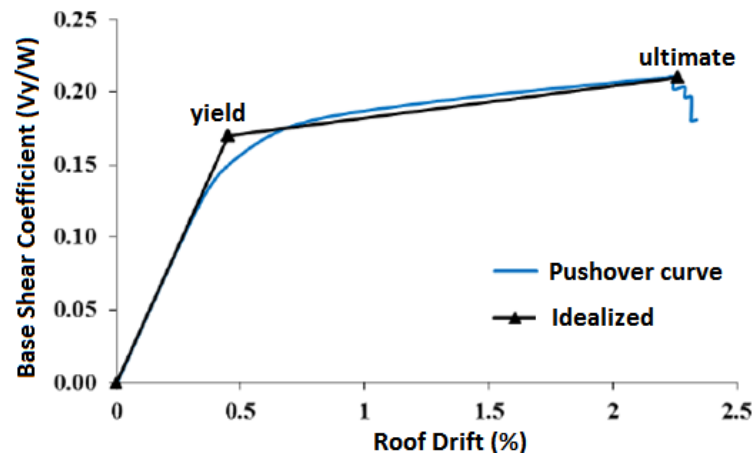

Fig 1. Typical pushover and idealized capacity curves [24]

\section{Properties of the Examined Building Models}

Within the scope of the study, a steel structure model having different number of floors and structural footprints was selected. The structure was selected symmetrically in both X and $Y$ axes. The analyses were performed with the academic licensed Seismostruct software. ZE selection was made in the software used for the structural basic soil class. It was considered IV class as the structural important class and $5 \%$ as the damping ratio.

Mathematical models are used for describing the stress-strain relationship for any material. The material model plays a very important role in the seismic structural analyses 
[25]. Calculations were made for steel model selected as Menegetto-Pinto steel model (stl_mp) [26] in this study. This model, proposed by Menegotto and Pinto, is widely used to simulate the cyclic response of steel structures and steel bars of reinforced concrete structures [27]. The stress-strain relationship for this steel model was given in Figure 2.

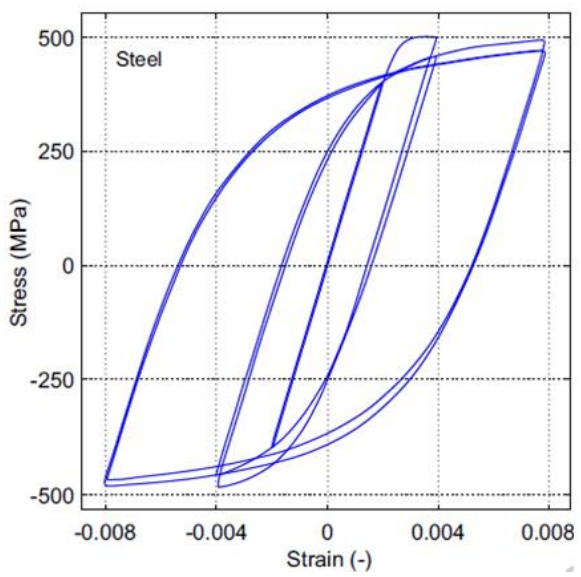

Fig 2. Stress-strain relation for Menegetto-Pinto steel model [20]

In the selected steel structure model, I300 bars were considered. In order to make comparisons in structural models, these bars were taken into consideration in all columns and beams in all structural models. The cross-sectional representation and the dimensions of the selected profile are shown in Figure 3.

\begin{tabular}{|c|c|c|}
\hline \multirow{4}{*}{} & \multicolumn{2}{|c|}{ Sections dimensions $(\mathrm{m})$} \\
\cline { 2 - 3 } & Bottom flange width & 0.100 \\
\cline { 2 - 3 } & Bottom flange thickness & 0.010 \\
\hline & Top flange width & 0.200 \\
\hline & Top flange thickness & 0.015 \\
\hline & Web height & 0.300 \\
\hline & Web thickness & 0.015 \\
\hline
\end{tabular}

Fig 3. Size and type of cross section of structural elements

Each axial clearances $(a, b)$ forming the footprint, the first parameter considered within the scope of the study, took different values. Figure 4 shows the formwork plan of steel structure considered in the study. 


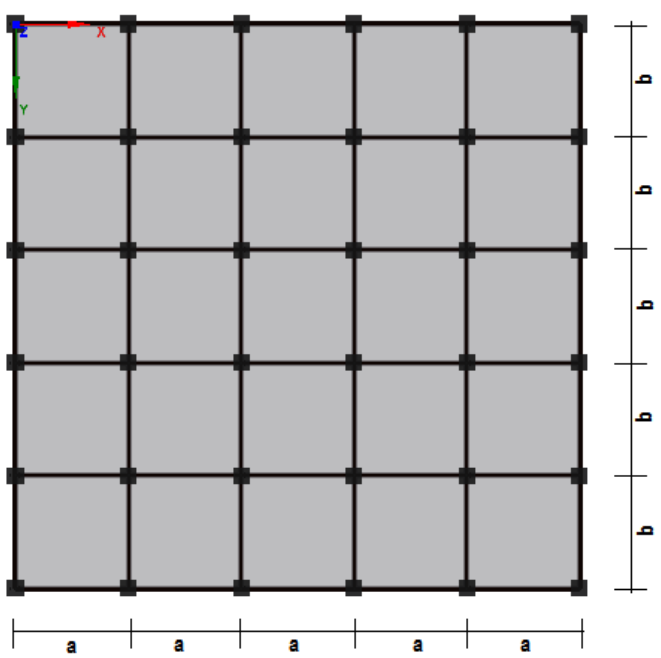

Fig 4. Floor formwork plan of steel structure model

Number of floors were kept constant and $a$ and $b$ values for footprint were selected as variables. For the values for a and b, five different cases were considered. Considered structural dimensions are given in Table 1.

Table 1. Considered structural dimensions for models

\begin{tabular}{cccc}
\hline Model No & $\mathrm{a}(\mathrm{m})$ & $\mathrm{b}(\mathrm{m})$ & Footprint area $\left(\mathrm{m}^{2)}\right.$ \\
\hline Model 1 & 4.0 & 4.0 & 400 \\
Model 2 & 4.5 & 4.5 & 506.25 \\
Model 3 & 5.0 & 5.0 & 625 \\
Model 4 & 5.5 & 5.5 & 756.25 \\
Model 5 & 6.0 & 6.0 & 900 \\
\hline
\end{tabular}

Figure 5 shows the 3-D structure models patterned by software in case of considering the different numbers of floors.

\section{The Results of Analysis}

Firstly, it was carried out by considering the different floor numbers. The results were obtained for five different structure models separately which were created by considering the five different footprints for each number of floors. Table 2 shows the comparison of values for periods and frequencies acquired via Eigenvalue analysis results for five-storey steel structure. 

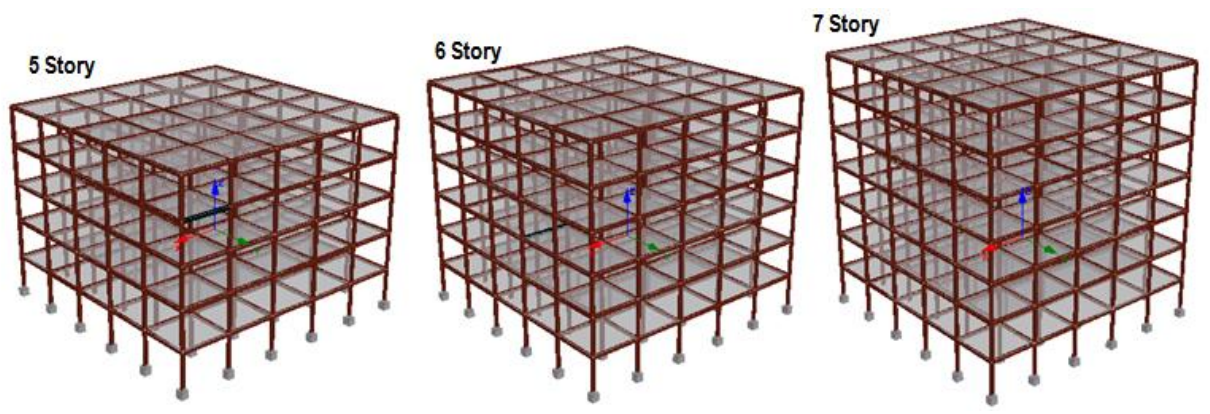

Fig 5. 3-D Models for steel structures with different numbers of floors

Figure 6 shows the 2-D structure models patterned for the selected numbers of floors, and the loads applied to the structure.
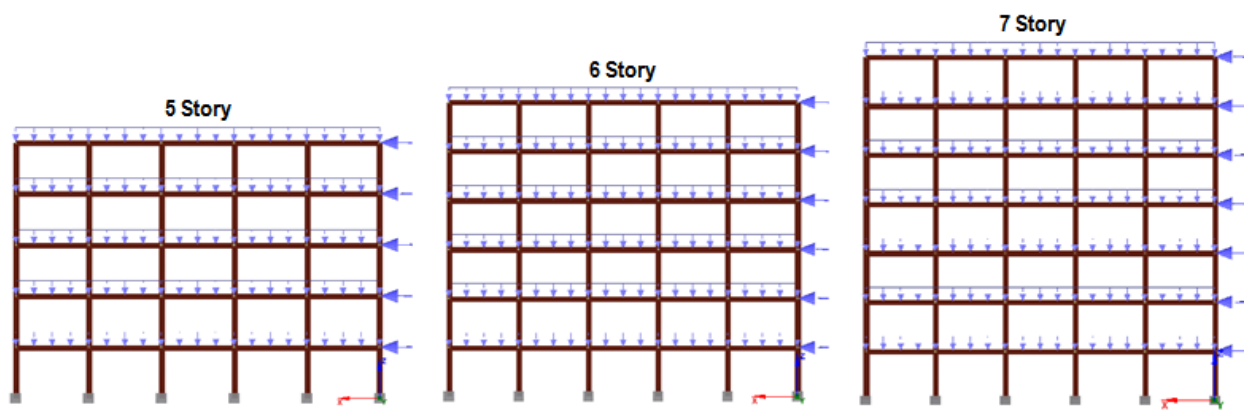

Fig 6. 2-D structure models for different numbers of floors and the applied loads

Table 2. The comparison of periods and frequencies for different footprints for 5-story

\begin{tabular}{ccccccccccc}
\hline & \multicolumn{1}{c}{ Period (sec) } \\
\cline { 2 - 12 } & Model & Model & Model & Model & Model & Model & Model & Model & Model & Model \\
& 1 & 2 & 3 & 4 & 5 & 1 & 2 & 3 & 4 & 5 \\
\hline 1 & 0.5957 & 0.6263 & 0.6562 & 0.6854 & 0.7141 & 1.6788 & 1.5967 & 1.5239 & 1.4589 & 1.4004 \\
2 & 0.3149 & 0.3370 & 0.3590 & 0.3807 & 0.4023 & 3.1755 & 2.9669 & 2.7856 & 2.6266 & 2.4860 \\
3 & 0.2537 & 0.2728 & 0.2919 & 0.3109 & 0.3299 & 3.9423 & 3.6655 & 3.4256 & 3.2160 & 3.0312 \\
4 & 0.2028 & 0.2130 & 0.2229 & 0.2326 & 0.2420 & 4.9301 & 4.6946 & 4.4860 & 4.2996 & 4.1317 \\
5 & 0.1273 & 0.1334 & 0.1394 & 0.1451 & 0.1508 & 7.8553 & 7.4945 & 7.1752 & 6.8901 & 6.6333 \\
6 & 0.1026 & 0.1094 & 0.1160 & 0.1226 & 0.1291 & 9.7479 & 9.1441 & 8.6176 & 8.1545 & 7.7440 \\
7 & 0.0981 & 0.1026 & 0.1069 & 0.1111 & 0.1151 & 10.189 & 9.7465 & 9.3544 & 9.0039 & 8.6881 \\
8 & 0.0855 & 0.0891 & 0.0934 & 0.0990 & 0.1046 & 11.701 & 11.217 & 10.710 & 10.099 & 9.5599 \\
9 & 0.0819 & 0.0877 & 0.0927 & 0.0961 & 0.0994 & 12.209 & 11.407 & 10.788 & 10.404 & 10.058 \\
10 & 0.0470 & 0.0499 & 0.0527 & 0.0555 & 0.0583 & 21.296 & 20.048 & 18.963 & 18.008 & 17.161 \\
\hline
\end{tabular}

Cumulative mass percentages acquired via Eigenvalue analyses are given in Table 3. 
Table 3. The acquired cumulative mass ratios for 5-story (\%)

\begin{tabular}{ccccccccccc}
\hline & \multicolumn{10}{c}{ Cumulative Mass Ratio (\%) } \\
\cline { 2 - 11 } Mode & \multicolumn{10}{c}{$\mathrm{U}_{\mathrm{x}}$} \\
\cline { 2 - 12 } & Model & Model & Model & Model & Model & Model & Model & Model & Model & Model \\
& 1 & 2 & 3 & 4 & 5 & 1 & 2 & 3 & 4 & 5 \\
\hline 1 & 0.00 & 0.00 & 0.00 & 0.00 & 0.00 & 87.33 & 87.25 & 87.18 & 87.10 & 87.03 \\
2 & 0.00 & 0.00 & 0.00 & 0.00 & 0.00 & 87.33 & 87.25 & 87.18 & 87.10 & 87.03 \\
3 & 83.80 & 83.58 & 83.36 & 83.15 & 82.95 & 87.33 & 87.25 & 87.18 & 87.10 & 87.03 \\
4 & 83.80 & 83.58 & 83.36 & 83.15 & 82.95 & 96.33 & 96.27 & 96.22 & 96.16 & 96.11 \\
5 & 83.80 & 83.58 & 83.36 & 83.15 & 82.95 & 98.95 & 98.93 & 98.90 & 98.88 & 98.85 \\
6 & 83.80 & 83.58 & 83.36 & 83.15 & 82.95 & 98.95 & 98.93 & 98.90 & 98.88 & 98.85 \\
7 & 83.80 & 83.58 & 83.36 & 83.15 & 82.95 & 99.81 & 99.81 & 99.80 & 99.79 & 99.79 \\
8 & 83.80 & 83.58 & 93.67 & 93.51 & 93.37 & 100.0 & 100.0 & 99.80 & 99.79 & 99.79 \\
9 & 94.03 & 93.84 & 93.67 & 93.51 & 93.37 & 100.0 & 100.0 & 100.0 & 100.0 & 100.0 \\
10 & 97.82 & 97.73 & 97.64 & 97.56 & 97.48 & 100.0 & 100.0 & 100.0 & 100.0 & 100.0 \\
\hline
\end{tabular}

Base shear forces were calculated separately for each number of floors and each structure model. The settlement on the idealized curve at the moment of flow (dy) was selected as settlement values. The values for elastic stiffness (K_elas) and effective stiffness (K_eff) were calculated separately. The target displacements for the damage of structure can also be calculated. Three different cases were defined for damages in software as follows: noncollapsing (NC), severe damage (SD) and damage limitation (DL). These values were calculated for all models by Seismostruct software [20]. Table 4 shows the comparison of all values on $\mathrm{X}$-axis as result of structural calculations.

Table 4. Acquired result for different 5-storey structural models

\begin{tabular}{cccccccc}
\hline Model & $\begin{array}{c}\text { Base Shear } \\
(\mathrm{kN})\end{array}$ & K_elas & K-eff & dy & DL & SD & NC \\
\hline 1 & 10129.84 & 54439.42 & 50487.68 & 0.2006 & 0.0170082 & 0.0218187 & 0.03782 \\
2 & 10036.24 & 51245.38 & 47776.49 & 0.2101 & 0.0195205 & 0.0250415 & 0.043413 \\
3 & 9915.62 & 48377.97 & 45351.85 & 0.2186 & 0.0221865 & 0.0284615 & 0.049342 \\
4 & 9774.18 & 45799.5 & 43185.76 & 0.2263 & 0.0249964 & 0.0320662 & 0.055591 \\
5 & 9617.92 & 43473.34 & 41195.64 & 0.2335 & 0.027977 & 0.0358898 & 0.062220 \\
\hline
\end{tabular}

Figure 7 shows the comparison of pushover curves for the structural models having different footprints in terms of the selected 5-storey. 


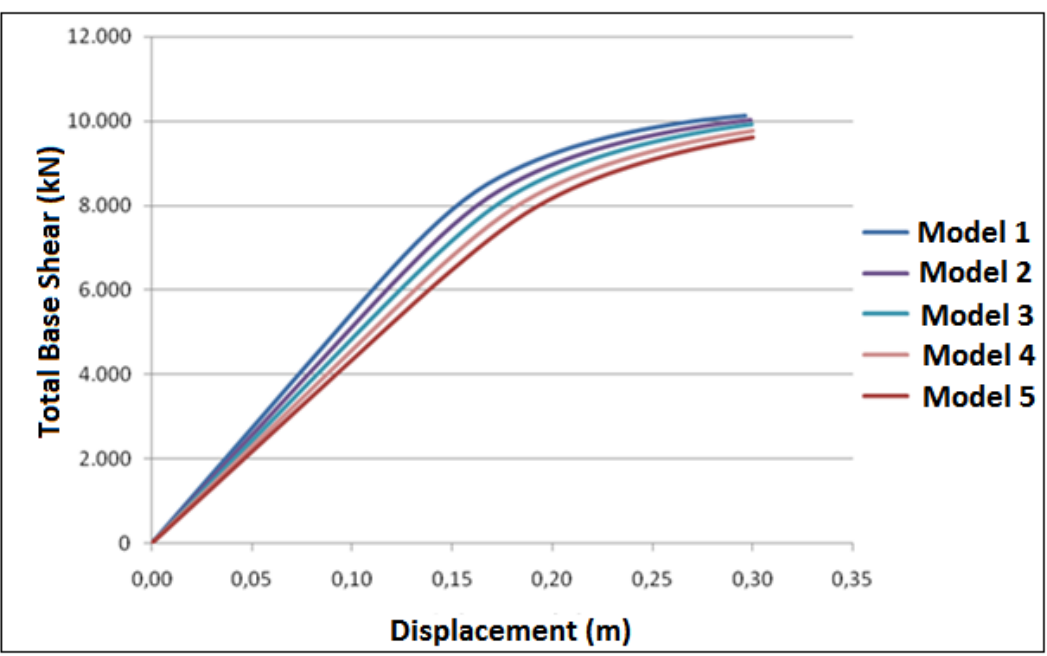

Fig 7. The comparison of pushover curves for 5-story for different structural models

The comparison of values for period and frequency obtained via eigenvalue analysis in terms of six-storey steel structure is given in Table 5.

Table 5. The comparison of period and frequency for different footprints of 6-story

\begin{tabular}{ccccccccccc}
\hline \multirow{4}{*}{ Mode } & \multicolumn{1}{c}{ Period (sec) } \\
\cline { 2 - 11 } & Model 1 & Model 2 & Model 3 & Model 4 & Model 5 & Model 1 & Model 2 & Model 3 & Model 4 & Model 5 \\
\hline 1 & 0.7086 & 0.7448 & 0.7802 & 0.8149 & 0.8489 & 1.4113 & 1.3426 & 1.2817 & 1.2271 & 1.1780 \\
2 & 0.3789 & 0.4055 & 0.4320 & 0.4583 & 0.4843 & 2.6393 & 2.4659 & 2.3148 & 2.1822 & 2.0648 \\
3 & 0.3058 & 0.3289 & 0.3520 & 0.3751 & 0.3981 & 3.2699 & 3.0403 & 2.8408 & 2.6661 & 2.5121 \\
4 & 0.2396 & 0.2516 & 0.2634 & 0.2749 & 0.2861 & 4.1736 & 3.9738 & 3.7966 & 3.6380 & 3.4950 \\
5 & 0.1480 & 0.1553 & 0.1623 & 0.1692 & 0.1758 & 6.7555 & 6.4402 & 6.1610 & 5.9115 & 5.6867 \\
6 & 0.1112 & 0.1164 & 0.1214 & 0.1263 & 0.1311 & 8.9921 & 8.5902 & 8.2342 & 7.9159 & 7.6292 \\
7 & 0.0993 & 0.1064 & 0.1135 & 0.1205 & 0.1275 & 10.072 & 9.3989 & 8.8125 & 8.2983 & 7.8440 \\
8 & 0.0932 & 0.0973 & 0.1013 & 0.1052 & 0.1089 & 10.734 & 10.276 & 9.8708 & 9.5077 & 9.1803 \\
9 & 0.0844 & 0.0881 & 0.0915 & 0.0949 & 0.0981 & 11.843 & 11.357 & 10.925 & 10.538 & 10.190 \\
10 & 0.0570 & 0.0608 & 0.0645 & 0.0681 & 0.0717 & 17.537 & 16.451 & 15.507 & 14.679 & 13.947 \\
\hline
\end{tabular}

Cumulative mass percentages obtained via eigenvalue analyses for six-story is given in Table 6. 
Table 6. Cumulative mass percentages for 6-story (\%)

\begin{tabular}{ccccccccccc}
\hline & \multicolumn{8}{c}{ Cumulative Mass Ratios (\%) } \\
\cline { 2 - 11 } Mode & \multicolumn{7}{c}{ Ux } & \multicolumn{7}{c}{ Uy } \\
\cline { 2 - 11 } & Model 1 & Model 2 & Model 3 & Model 4 & Model 5 & Model 1 & Model 2 & Model 3 & Model 4 & Model 5 \\
\hline 1 & 0.00 & 0.00 & 0.00 & 0.00 & 0.00 & 86.33 & 86.27 & 86.21 & 86.15 & 86.09 \\
2 & 0.00 & 0.00 & 0.00 & 0.00 & 0.00 & 86.33 & 86.27 & 86.21 & 86.15 & 86.09 \\
3 & 83.11 & 82.94 & 82.77 & 82.59 & 82.42 & 86.33 & 86.27 & 86.21 & 86.15 & 86.09 \\
4 & 83.11 & 82.94 & 82.77 & 82.59 & 82.42 & 95.49 & 95.44 & 95.38 & 95.33 & 95.28 \\
5 & 83.11 & 82.94 & 82.77 & 82.59 & 82.42 & 98.36 & 98.33 & 98.30 & 98.27 & 98.24 \\
6 & 83.11 & 82.94 & 82.77 & 82.59 & 82.42 & 99.49 & 99.48 & 99.46 & 99.45 & 99.44 \\
7 & 93.18 & 93.01 & 92.84 & 92.69 & 92.54 & 99.49 & 99.48 & 99.46 & 99.45 & 99.44 \\
8 & 93.18 & 93.01 & 92.84 & 92.69 & 92.54 & 99.91 & 99.90 & 99.90 & 99.90 & 99.89 \\
9 & 93.18 & 93.01 & 92.84 & 92.69 & 92.54 & 100.00 & 100.00 & 100.00 & 100.00 & 100.00 \\
10 & 96.95 & 96.84 & 96.73 & 96.63 & 96.54 & 100.00 & 100.00 & 100.00 & 100.00 & 100.00 \\
\hline
\end{tabular}

Table 7 shows the comparison of all the values obtained in $\mathrm{X}$ direction as a result of structural calculations for six-story.

Table 7. The results regarding different structural models for 6-story

\begin{tabular}{cccccccc}
\hline Model & $\begin{array}{c}\text { Base } \\
\text { Shear } \\
(\mathrm{kN})\end{array}$ & K_elas & K-eff & dy & DL & SD & NC \\
\hline 1 & 9973.31 & 45173.69 & 42057.11 & 0.2371 & 0.0244309 & 0.0313408 & 0.0543339 \\
2 & 9927.44 & 42495.9 & 39590.28 & 0.2508 & 0.028191 & 0.0361643 & 0.0626961 \\
3 & 9785.38 & 40077.23 & 37677.5 & 0.2597 & 0.0319625 & 0.0410026 & 0.071084 \\
4 & 9642.14 & 37893.41 & 35832.92 & 0.2691 & 0.036059 & 0.0462577 & 0.0801945 \\
5 & 9487.23 & 35917.72 & 34121.58 & 0.278 & 0.0404328 & 0.0518685 & 0.0899217 \\
\hline
\end{tabular}

The comparison of pushover curves for structure models with different footprints in terms of six-story structure is given in Figure 8. 


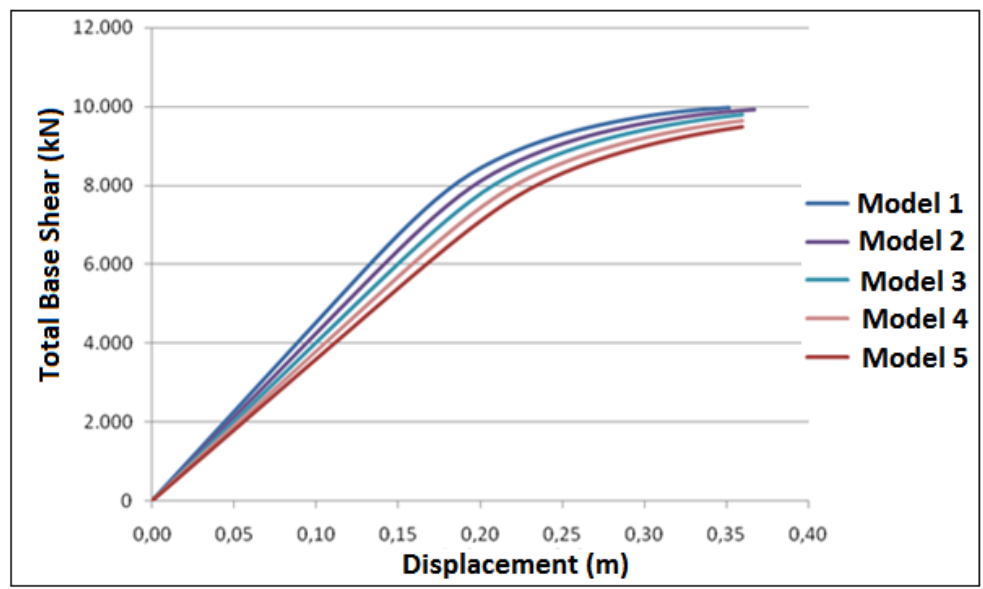

Fig 8. The comparison of pushover curves for 6-story

The comparison of values for period and frequency obtained via eigenvalue analysis in terms of seven-story steel structure is given in Table 8.

Table 8. The comparison of period and frequency for different footprints of 7-story

\begin{tabular}{ccccccccccc}
\hline \multirow{4}{*}{ Mode } & \multicolumn{9}{c}{ Period (sec) } \\
\cline { 2 - 11 } & Model 1 & Model 2 & Model 3 & Model 4 & Model 5 & Model 1 & Model 2 & Model 3 & Model 4 & Model 5 \\
\hline 1 & 0.8218 & 0.8636 & 0.9045 & 0.9446 & 0.9840 & 1.2169 & 1.1579 & 1.1055 & 1.0586 & 1.0163 \\
2 & 0.4431 & 0.4742 & 0.5052 & 0.5359 & 0.5665 & 2.2567 & 2.1086 & 1.9794 & 1.8659 & 1.7653 \\
3 & 0.3583 & 0.3853 & 0.4124 & 0.4394 & 0.4664 & 2.7907 & 2.5953 & 2.4250 & 2.2757 & 2.1439 \\
4 & 0.2767 & 0.2907 & 0.3042 & 0.3175 & 0.3306 & 3.6135 & 3.4405 & 3.2869 & 3.1493 & 3.0251 \\
5 & 0.1694 & 0.1777 & 0.1859 & 0.1938 & 0.2016 & 5.9042 & 5.6259 & 5.3793 & 5.1588 & 4.9601 \\
6 & 0.1254 & 0.1552 & 0.1371 & 0.1428 & 0.1842 & 7.9773 & 6.4442 & 7.2918 & 7.0037 & 5.4280 \\
7 & 0.1168 & 0.1313 & 0.1337 & 0.1421 & 0.1505 & 8.5601 & 7.6139 & 7.4776 & 7.0352 & 6.6442 \\
8 & 0.1027 & 0.1253 & 0.1119 & 0.1163 & 0.1483 & 9.7395 & 7.9815 & 8.9345 & 8.5962 & 6.7441 \\
9 & 0.0902 & 0.1074 & 0.0980 & 0.1017 & 0.1206 & 11.087 & 9.3127 & 10.205 & 9.8347 & 8.2913 \\
10 & 0.0838 & 0.0942 & 0.0908 & 0.0941 & 0.1053 & 11.935 & 10.620 & 11.013 & 10.624 & 9.5003 \\
\hline
\end{tabular}

Cumulative mass percentages obtained via eigenvalue analyses for seven-story is given in Table 9. 
Table 9. Cumulative mass percentages for 7-story (\%)

\begin{tabular}{cccccccccccc}
\hline & \multicolumn{10}{c}{ Cumulative Mass (\%) } \\
\cline { 2 - 11 } Mode & \multicolumn{9}{c}{ Ux } & \multicolumn{7}{c}{ Uy } \\
\cline { 2 - 11 } & Model 1 & Model 2 & Model 3 & Model 4 & Model 5 & Model 1 & Model 2 & Model 3 & Model 4 & Model 5 \\
\hline 1 & 0.00 & 0.00 & 0.00 & 0.00 & 0.00 & 85.59 & 85.55 & 85.50 & 85.45 & 85.39 \\
2 & 0.00 & 0.00 & 0.00 & 0.00 & 0.00 & 85.59 & 85.55 & 85.50 & 85.45 & 85.39 \\
3 & 82.62 & 82.49 & 82.35 & 82.21 & 82.07 & 85.59 & 85.55 & 85.50 & 85.45 & 85.39 \\
4 & 82.62 & 82.49 & 82.35 & 82.21 & 82.07 & 94.84 & 94.79 & 94.73 & 94.68 & 94.64 \\
5 & 82.62 & 82.49 & 82.35 & 82.21 & 82.07 & 97.85 & 97.81 & 97.78 & 97.74 & 97.71 \\
6 & 82.62 & 82.49 & 82.35 & 82.21 & 82.07 & 99.14 & 97.81 & 99.10 & 99.08 & 97.71 \\
7 & 92.60 & 82.49 & 92.27 & 92.13 & 91.99 & 99.14 & 99.12 & 99.10 & 99.08 & 97.71 \\
8 & 92.60 & 92.43 & 92.27 & 92.13 & 91.99 & 99.72 & 99.12 & 99.70 & 99.70 & 99.06 \\
9 & 92.60 & 92.43 & 92.27 & 92.13 & 91.99 & 99.95 & 99.71 & 99.94 & 99.94 & 99.69 \\
10 & 92.60 & 92.43 & 92.27 & 92.13 & 91.99 & 100.00 & 99.95 & 100.00 & 100.00 & 99.94 \\
\hline
\end{tabular}

Table 10 shows the comparison of all the values obtained in $\mathrm{X}$ direction as a result of structural calculations for seven-storey.

Table 10. The results regarding different models for 7-story

\begin{tabular}{cccccccc}
\hline Model & $\begin{array}{c}\text { Base Shear } \\
(\mathrm{kN})\end{array}$ & K_elas & K-eff & dy & DL & SD & NC \\
\hline 1 & 9804.68 & 38497.59 & 36142.38 & 0.2713 & 0.033095 & 0.042455 & 0.073602 \\
2 & 9752.97 & 36215.03 & 33998.07 & 0.2869 & 0.038224 & 0.049035 & 0.085009 \\
3 & 9650.17 & 34138.44 & 32132.03 & 0.3003 & 0.043647 & 0.055992 & 0.09707 \\
4 & 9507.19 & 32254.17 & 30578.88 & 0.3109 & 0.049216 & 0.063136 & 0.109455 \\
5 & 9350.52 & 30543.45 & 29085.36 & 0.3215 & 0.055255 & 0.070883 & 0.122886 \\
\hline
\end{tabular}

The comparison of pushover curves for structure models with different footprints in terms of seven-story structure is given in Figure 9. 


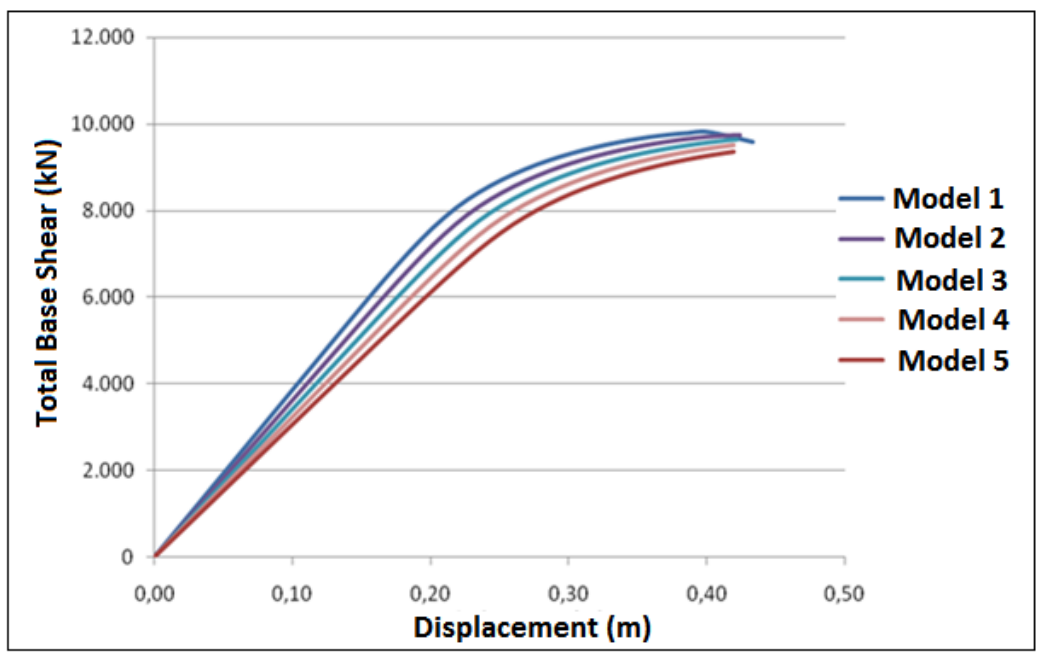

Fig 9. The comparison of pushover curves for 7-storey having different footprints

Additional comparisons for each steel structure model with same footprints but different number of floors were performed separately. The comparison of pushover curves for the changing numbers of floors in terms of Model 1 is given in Figure 10.

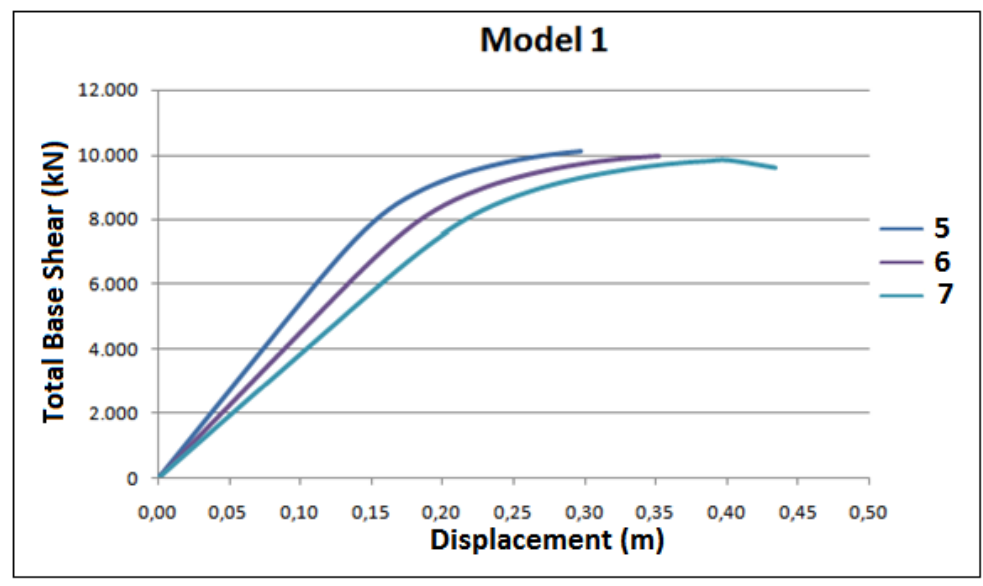

Fig 10. The comparison of pushover curves for Model 1 having different numbers of floors but same footprints.

The change of obtained values in terms of number of floors is given in Table 11. 
Table 11a. The comparison of result values for structure models having different footprints in terms of change in number of floors

\begin{tabular}{ccccccc}
\hline \multirow{\Xi}{*}{$\overline{0}$} & \multicolumn{3}{c}{ Base Shear $(\mathrm{kN})$} & \multicolumn{3}{c}{ K_elas } \\
\cline { 2 - 7 }$\Sigma$ & 5 Story & 6 Story & 7 Story & 5 Story & 6 Story & 7 Story \\
\hline 1 & 10129.8 & 9973.3 & 9804.6 & 54439.4 & 45173.6 & 38497.5 \\
2 & 10036.2 & 9927.4 & 9752.9 & 51245.3 & 42495.9 & 36215.0 \\
3 & 9915.6 & 9785.3 & 9650.1 & 48377.9 & 40077.2 & 34138.4 \\
4 & 9774.1 & 9642.1 & 9507.1 & 45799.5 & 37893.4 & 32254.1 \\
5 & 9617.9 & 9487.2 & 9350.5 & 43473.3 & 35917.7 & 30543.4 \\
\hline
\end{tabular}

Table 11b. The comparison of result values for structure models having different footprints in terms of change in number of floors

\begin{tabular}{ccccccc}
\hline $\bar{\Xi}$ & \multicolumn{3}{c}{ K-eff } & \multicolumn{3}{c}{ dy } \\
\cline { 2 - 7 }$\sum_{\Sigma}^{\circ}$ & 5 Story & 6 Story & 7 Story & 5 Story & 6 Story & 7 Story \\
\hline 1 & 50487.6 & 42057.1 & 36142.3 & 0.200 & 0.237 & 0.271 \\
2 & 47776.4 & 39590.2 & 33998.0 & 0.210 & 0.250 & 0.286 \\
3 & 45351.8 & 37677.5 & 32132.0 & 0.218 & 0.259 & 0.300 \\
4 & 43185.7 & 35832.9 & 30578.8 & 0.226 & 0.269 & 0.310 \\
5 & 41195.6 & 34121.5 & 29085.3 & 0.233 & 0.278 & 0.321 \\
\hline
\end{tabular}

The whole comparison of pushover curves for Model 2, Model 3, Model 4 and Model 5 having different numbers of floors but same footprints is given in Figure 11. 


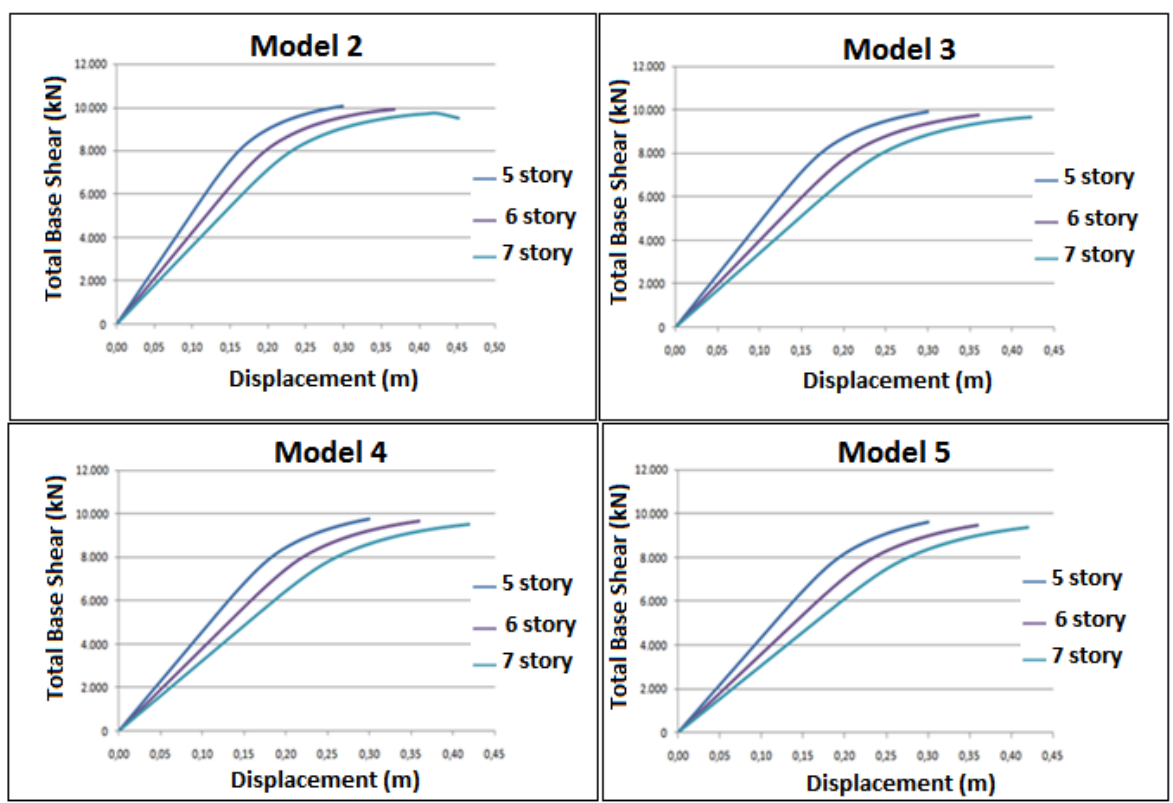

Fig 11. The comparison of pushover curves models having different numbers of floors but same footprints

The change of target displacement values as performance criteria in terms of footprints and number of floors obtained via software is given in Table 12.

Table 12. The comparison of target displacement values

\begin{tabular}{cccccccccc}
\hline \multirow{2}{*}{ Model } & \multicolumn{3}{c}{ DL } & \multicolumn{3}{c}{ SD } & \multicolumn{3}{c}{ NC } \\
\cline { 2 - 9 } & 5 Story & 6 Story & 7 Story & 5 Story & 6 Story & 7 Story & 5 Story & 6 Story & 7 Story \\
\hline 1 & 0.017 & 0.0244 & 0.0330 & 0.0218 & 0.0313 & 0.0424 & 0.0378 & 0.0543 & 0.0736 \\
2 & 0.019 & 0.0281 & 0.0382 & 0.0250 & 0.0361 & 0.0490 & 0.0434 & 0.0627 & 0.0850 \\
3 & 0.022 & 0.0319 & 0.0435 & 0.0284 & 0.0410 & 0.0559 & 0.0493 & 0.0710 & 0.0970 \\
4 & 0.025 & 0.0360 & 0.0492 & 0.0320 & 0.0462 & 0.0631 & 0.0555 & 0.0801 & 0.1094 \\
5 & 0.027 & 0.0404 & 0.0552 & 0.0358 & 0.05187 & 0.07088 & 0.06222 & 0.08992 & 0.12289 \\
\hline
\end{tabular}

The comparison of period values obtained for all the number of floors and structure models having different footprints is given in Table 13. 
Table 13. The comparison of period values for all the structure models

\begin{tabular}{|c|c|c|c|c|c|c|c|c|c|c|c|c|c|c|c|}
\hline \multirow{3}{*}{$\begin{array}{l}\frac{0}{0} \\
\text { ¿ }\end{array}$} & \multicolumn{15}{|c|}{ Period (sec) } \\
\hline & \multicolumn{3}{|c|}{ Model 1} & \multicolumn{3}{|c|}{ Model 2} & \multicolumn{3}{|c|}{ Model 3} & \multicolumn{3}{|c|}{ Model 4} & \multicolumn{3}{|c|}{ Model 5} \\
\hline & 5 & 6 & 7 & 5 & 6 & 7 & 5 & 6 & 7 & 5 & 6 & 7 & 5 & 6 & 7 \\
\hline 1 & 0.595 & 0.708 & 0.821 & 0.626 & 0.744 & 0.863 & 0.656 & 0.780 & 0.904 & 0.685 & 0.814 & 0.944 & 0.714 & 0.848 & 0.984 \\
\hline 2 & 0.314 & 0.378 & 0.443 & 0.337 & 0.405 & 0.474 & 0.359 & 0.432 & 0.505 & 0.380 & 0.458 & 0.535 & 0.402 & 0.484 & 0.566 \\
\hline 3 & 0.253 & 0.305 & 0.358 & 0.272 & 0.328 & 0.385 & 0.291 & 0.352 & 0.412 & 0.310 & 0.375 & 0.439 & 0.329 & 0.398 & 0.466 \\
\hline 4 & 0.202 & 0.239 & 0.276 & 0.213 & 0.251 & 0.290 & 0.222 & 0.263 & 0.304 & 0.232 & 0.274 & 0.317 & 0.242 & 0.286 & 0.330 \\
\hline 5 & 0.127 & 0.148 & 0.169 & 0.133 & 0.155 & 0.177 & 0.139 & 0.162 & 0.185 & 0.145 & 0.169 & 0.193 & 0.150 & 0.175 & 0.201 \\
\hline 6 & 0.102 & 0.111 & 0.125 & 0.109 & 0.116 & 0.155 & 0.116 & 0.121 & 0.137 & 0.122 & 0.126 & 0.142 & 0.129 & 0.131 & 0.184 \\
\hline 7 & 0.098 & 0.099 & 0.116 & 0.102 & 0.106 & 0.131 & 0.106 & 0.113 & 0.133 & 0.111 & 0.120 & 0.142 & 0.115 & 0.127 & 0.150 \\
\hline 8 & 0.085 & 0.093 & 0.102 & 0.089 & 0.097 & 0.125 & 0.093 & 0.101 & 0.111 & 0.099 & 0.105 & 0.116 & 0.104 & 0.108 & 0.148 \\
\hline 9 & 0.081 & 0.084 & 0.090 & 0.087 & 0.088 & 0.107 & 0.092 & 0.091 & 0.098 & 0.096 & 0.094 & 0.101 & 0.099 & 0.098 & 0.120 \\
\hline 10 & 0.047 & 0.057 & 0.083 & 0.049 & 0.060 & 0.094 & 0.052 & 0.064 & 0.090 & 0.055 & 0.068 & 0.094 & 0.058 & 0.071 & 0.105 \\
\hline
\end{tabular}

The comparison in percentage of cumulative participation mass ratios in $\mathrm{X}$ direction obtained via eigenvalue analyses and values considered within the scope of the study is given in Table 14. The comparison in percentage of cumulative participation mass ratios in $\mathrm{Y}$ direction is given in Table 15.

Table 14. The comparison of cumulative participation mass ratios in $\mathrm{X}$ direction

\begin{tabular}{|c|c|c|c|c|c|c|c|c|c|c|c|c|c|c|c|}
\hline \multirow{3}{*}{$\frac{0}{\frac{0}{0}}$} & \multicolumn{15}{|c|}{ Cumulative Mass $(\%)\left(U_{X}\right)$} \\
\hline & \multicolumn{3}{|c|}{ Model 1} & \multicolumn{3}{|c|}{ Model 2} & \multicolumn{3}{|c|}{ Model 3} & \multicolumn{3}{|c|}{ Model 4} & \multicolumn{3}{|c|}{ Model 5} \\
\hline & 5 & 6 & 7 & 5 & 6 & 7 & 5 & 6 & 7 & 5 & 6 & 7 & 5 & 6 & 7 \\
\hline 1 & 0.00 & 0.00 & 0.00 & 0.00 & 0.00 & 0.00 & 0.00 & 0.00 & 0.00 & 0.00 & 0.00 & 0.00 & 0.00 & 0.00 & 0.00 \\
\hline 2 & 0.00 & 0.00 & 0.00 & 0.00 & 0.00 & 0.00 & 0.00 & 0.00 & 0.00 & 0.00 & 0.00 & 0.00 & 0.00 & 0.00 & 0.00 \\
\hline 3 & 83.8 & 83.1 & 82.6 & 83.5 & 82.9 & 82.4 & 83.3 & 82.7 & 82.3 & 83.1 & 82.5 & 82.2 & 82.9 & 82.4 & 82.0 \\
\hline 4 & 83.8 & 83.1 & 82.6 & 83.5 & 82.9 & 82.4 & 83.3 & 82.7 & 82.3 & 83.1 & 82.5 & 82.2 & 82.9 & 82.4 & 82.0 \\
\hline 5 & 83.8 & 83.1 & 82.6 & 83.5 & 82.9 & 82.4 & 83.3 & 82.7 & 82.3 & 83.1 & 82.5 & 82.2 & 82.9 & 82.4 & 82.0 \\
\hline 6 & 83.8 & 83.1 & 82.6 & 83.5 & 82.9 & 82.4 & 83.3 & 82.7 & 82.3 & 83.1 & 82.5 & 82.2 & 82.9 & 82.4 & 82.0 \\
\hline 7 & 83.8 & 93.1 & 92.6 & 83.5 & 93.0 & 82.4 & 83.3 & 92.8 & 92.2 & 83.1 & 92.6 & 92.1 & 82.9 & 92.5 & 91.9 \\
\hline 8 & 83.8 & 93.1 & 92.6 & 83.5 & 93.0 & 92.4 & 93.6 & 92.8 & 92.2 & 93.5 & 92.6 & 92.1 & 93.3 & 92.5 & 91.9 \\
\hline 9 & 94.0 & 93.1 & 92.6 & 93.8 & 93.0 & 92.4 & 93.6 & 92.8 & 92.2 & 93.5 & 92.6 & 92.1 & 93.3 & 92.5 & 91.9 \\
\hline 10 & 97.8 & 96.9 & 92.6 & 97.7 & 96.8 & 92.4 & 97.6 & 96.7 & 92.2 & 97.5 & 96.6 & 92.1 & 97.4 & 96.5 & 91.9 \\
\hline
\end{tabular}


Table 15. The comparison of cumulative participation mass ratios in Y direction

\begin{tabular}{|c|c|c|c|c|c|c|c|c|c|c|c|c|c|c|c|}
\hline \multirow{3}{*}{$\begin{array}{l}\frac{0}{0} \\
\sum\end{array}$} & \multicolumn{15}{|c|}{ Cumulative Mass $(\%)\left(\mathrm{U}_{\mathrm{Y}}\right)$} \\
\hline & \multicolumn{3}{|c|}{ Model 1} & \multicolumn{3}{|c|}{ Model 2} & \multicolumn{3}{|c|}{ Model 3} & \multicolumn{3}{|c|}{ Model 4} & \multicolumn{3}{|c|}{ Model 5} \\
\hline & 5 & 6 & 7 & 5 & 6 & 7 & 5 & 6 & 7 & 5 & 6 & 7 & 5 & 6 & 7 \\
\hline 1 & 87.3 & 86.3 & 85.5 & 87.2 & 86.2 & 85.5 & 87.1 & 86.2 & 85.5 & 87.1 & 86.1 & 85.4 & 87.0 & 86.0 & 85.3 \\
\hline 2 & 87.3 & 86.3 & 85.5 & 87.2 & 86.2 & 85.5 & 87.1 & 86.2 & 85.5 & 87.1 & 86.1 & 85.4 & 87.0 & 86.0 & 85.3 \\
\hline 3 & 87.3 & 86.3 & 85.5 & 87.2 & 86.2 & 85.5 & 87.1 & 86.2 & 85.5 & 87.1 & 86.1 & 85.4 & 87.0 & 86.0 & 85.3 \\
\hline 4 & 96.3 & 95.4 & 94.8 & 96.2 & 95.4 & 94.7 & 96.2 & 95.3 & 94.7 & 96.1 & 95.3 & 94.6 & 96.1 & 95.2 & 94.6 \\
\hline 5 & 98.9 & 98.3 & 97.8 & 98.9 & 98.3 & 97.8 & 98.9 & 98.3 & 97.7 & 98.8 & 98.2 & 97.7 & 98.8 & 98.2 & 97.7 \\
\hline 6 & 98.9 & 99.4 & 99.1 & 98.9 & 99.4 & 97.8 & 98.9 & 99.4 & 99.1 & 98.8 & 99.4 & 99.0 & 98.8 & 99.4 & 97.7 \\
\hline 7 & 99.8 & 99.4 & 99.1 & 99.8 & 99.4 & 99.1 & 99.8 & 99.4 & 99.1 & 99.7 & 99.4 & 99.0 & 99.7 & 99.4 & 97.7 \\
\hline 8 & 100 & 99.9 & 99.7 & 100. & 99.9 & 99.1 & 99.8 & 99.9 & 99.7 & 99.7 & 99.9 & 99.7 & 99.7 & 99.8 & 99.0 \\
\hline 9 & 100 & 100 & 99.9 & 100 & 100 & 99.7 & 100 & 100 & 99.9 & 100 & 100 & 99.9 & 100 & 100 & 99.6 \\
\hline 10 & 100 & 100 & 100 & 100 & 100 & 99.9 & 100 & 100 & 100 & 100 & 100 & 100 & 100 & 100 & 99.9 \\
\hline
\end{tabular}

When making comparisons, in the first stage, footprints were kept constant. Table 16 shows the percentages of changes for different parameters resulting from changing of footprints. When calculating the percentage of changes, Model 1 having the smallest footprint was selected as a reference. Percentage of changes of each model according to Model 1 was calculated separately. The maximum period value was considered as the period value. Since negligible differences among the percentages of changes in terms of the values for non-collapsing (NC), severe damage (SD) and damage limitation (DL), the percentages of change in these three conditions were calculated only for DL. Comparison of all results obtained via pushover analyses is shown in Table 16. 
Table 16. Comparison of all the result values for different footprints (\%)

\begin{tabular}{|c|c|c|c|c|c|c|}
\hline Parameter & Story Number & Model 1 & Model 2 & Model 3 & Model 4 & Model 5 \\
\hline \multirow{3}{*}{ Period (sec) } & 5 & 0 & 5.14 & 10.16 & 15.07 & 19.88 \\
\hline & 6 & 0 & 5.12 & 10.17 & 15.01 & 19.81 \\
\hline & 7 & 0 & 5.09 & 10.07 & 14.95 & 19.74 \\
\hline \multirow{3}{*}{$\begin{array}{l}\text { Total Base } \\
\text { Shear }(\mathrm{kN})\end{array}$} & 5 & 0 & 0.92 & 2.11 & 3.51 & 5.05 \\
\hline & 6 & 0 & 0.46 & 1.88 & 3.32 & 4.87 \\
\hline & 7 & 0 & 0.42 & 1.58 & 3.03 & 4.63 \\
\hline \multirow{3}{*}{ K_Elas } & 5 & 0 & 5.87 & 11.13 & 15.87 & 20.14 \\
\hline & 6 & 0 & 5.93 & 11.28 & 16.12 & 20.49 \\
\hline & 7 & 0 & 5.93 & 11.32 & 16.22 & 20.57 \\
\hline \multirow{3}{*}{ K_eff } & 5 & 0 & 5.37 & 10.17 & 14.46 & 18.40 \\
\hline & 6 & 0 & 5.87 & 10.41 & 14.80 & 18.87 \\
\hline & 7 & 0 & 5.93 & 11.10 & 15.39 & 19.53 \\
\hline \multirow{3}{*}{ dy $(m)$} & 5 & 0 & 4.74 & 8.97 & 12.81 & 16.40 \\
\hline & 6 & 0 & 5.78 & 9.53 & 13.50 & 17.25 \\
\hline & 7 & 0 & 5.85 & 10.68 & 14.60 & 18.50 \\
\hline \multirow{3}{*}{ DL - SD - NC } & 5 & 0 & 14.82 & 30.47 & 47.00 & 64.53 \\
\hline & 6 & 0 & 15.40 & 30.82 & 47.61 & 65.49 \\
\hline & 7 & 0 & 15.50 & 31.88 & 48.62 & 66.97 \\
\hline
\end{tabular}

In the second stage of comparisons, the change in the number of floors was examined. Percentages of changes obtained as a result of differentiation of the number of floors are given in Table 17.

In the study, economic differences were also revealed by considering footprints and the number of floors. For this reason, the unit price determined for finding the approximate costs of structures in Turkey were used. According to "The Bulletin on the Approximate Unit Costs of Structures for 2019 to be used in the Account of Architectural and Engineering Fees" which was published in the Official Gazette by the Ministry of Environment and Urbanization [28], cost of structures in IV. Class Structures - Group A is $1270 \mathrm{TL} / \mathrm{m}^{2}$. According to the currency values provided by the Turkish Central Bank, this value is approximately $225 \$ / \mathrm{m}^{2}$ today. Structural damage-led financial losses were estimated by multiplying total damaged constructional area and unit cost. Cost calculations for different structure models and number of floors are given in Table 18. 
Table 17. Comparison of result values in terms of change in the number of floors (\%)

\begin{tabular}{|c|c|c|c|c|}
\hline Parameter & Model & 5 Story & 6 Story & 7 Story \\
\hline \multirow{5}{*}{ Period (sec) } & Model 1 & 0 & 18.95 & 37.96 \\
\hline & Model 2 & 0 & 18.92 & 37.89 \\
\hline & Model 3 & 0 & 18.90 & 37.84 \\
\hline & Model 4 & 0 & 18.89 & 37.82 \\
\hline & Model 5 & 0 & 18.88 & 37.80 \\
\hline \multirow{5}{*}{$\begin{array}{l}\text { Total Base } \\
\text { Shear }(\mathrm{kN})\end{array}$} & Model 1 & 0 & 1.54 & 3.21 \\
\hline & Model 2 & 0 & 1.49 & 2.83 \\
\hline & Model 3 & 0 & 1.37 & 2.78 \\
\hline & Model 4 & 0 & 1.35 & 2.73 \\
\hline & Model 5 & 0 & 1.35 & 2.67 \\
\hline \multirow{5}{*}{ K_Elas } & Model 1 & 0 & 17.02 & 29.28 \\
\hline & Model 2 & 0 & 17.07 & 29.33 \\
\hline & Model 3 & 0 & 17.16 & 29.43 \\
\hline & Model 4 & 0 & 17.26 & 29.57 \\
\hline & Model 5 & 0 & 17.38 & 29.74 \\
\hline \multirow{5}{*}{ K_eff } & Model 1 & 0 & 16.69 & 28.41 \\
\hline & Model 2 & 0 & 17.13 & 28.84 \\
\hline & Model 3 & 0 & 17.43 & 29.15 \\
\hline & Model 4 & 0 & 17.52 & 29.20 \\
\hline & Model 5 & 0 & 17.67 & 29.40 \\
\hline \multirow{5}{*}{ dy (m) } & Model 1 & 0 & 18.20 & 35.24 \\
\hline & Model 2 & 0 & 18.37 & 36.55 \\
\hline & Model 3 & 0 & 18.80 & 37.37 \\
\hline & Model 4 & 0 & 18.91 & 37.38 \\
\hline & Model 5 & 0 & 19.May & 37.68 \\
\hline \multirow{5}{*}{$\mathrm{DL}$ - SD - NC } & Model 1 & 0 & 43.62 & 94.53 \\
\hline & Model 2 & 0 & 43.92 & 95.80 \\
\hline & Model 3 & 0 & 44.02 & 96.71 \\
\hline & Model 4 & 0 & 44.24 & 96.88 \\
\hline & Model 5 & 0 & 44.49 & 97.46 \\
\hline
\end{tabular}

Table 18. Cost values for the selected steel structure having different footprints and number of floors 


\begin{tabular}{lcccccccc}
\hline \multirow{2}{*}{ Model } & \multicolumn{2}{c}{ Total Construction Area $\left(\mathrm{m}^{2}\right)$} & Unit & \multicolumn{3}{c}{ Total Cost $(\$)$} \\
\cline { 2 - 3 } \cline { 8 - 9 } & 5 Storey & 6 Storey & 7 Storey & $\begin{array}{c}\text { Cost } \\
\left(\$ / \mathrm{m}^{2}\right)\end{array}$ & 5 Storey & 6 Storey & 7 Storey \\
\hline Model 1 & 2000 & 2400 & 2800 & 225 & 450000 & 540000 & 630000 \\
Model 2 & 2531.25 & 3037.5 & 3543.75 & 225 & 569531.25 & 683437.5 & 797343.75 \\
Model 3 & 3125 & 3750 & 4375 & 225 & 703125 & 843750 & 984375 \\
Model 4 & 3781.25 & 4537.5 & 5293.75 & 225 & 850781.25 & 1020937.5 & 1191093.8 \\
Model 5 & 4500 & 5400 & 6300 & 225 & 1012500 & 1215000 & 1417500 \\
\hline
\end{tabular}

For cost comparisons between the models, the number of floors and total constructional area were selected as two different variables. When comparing the number of floors, the five-storey steel structure was chosen as the Model 1 reference structure with the lowest total construction area for the total construction area. The cost change rates calculated according to the selected reference structures are given in Table 19.

Table 19. Percentage of change of number of floors and footprints on cost (\%)

\begin{tabular}{cccccccc}
\hline & Model & \multicolumn{3}{c}{ Footprint Area } & \multicolumn{3}{c}{ Storey Number } \\
\cline { 2 - 8 } Total & 5 Story & 6 Story & 7 Story & 5 Story & 6 Story & 7 Story \\
\cline { 2 - 8 } Cost & Model 1 & 0 & 0 & 0 & 0 & 20 & 40 \\
Change & Model 2 & 26.55 & 26.55 & 26.55 & 0 & 20 & 40 \\
(\%) & Model 3 & 56.25 & 56.25 & 56.25 & 0 & 20 & 40 \\
& Model 4 & 89.05 & 89.05 & 89.05 & 0 & 20 & 40 \\
& Model 5 & 125 & 125 & 125 & 0 & 20 & 40 \\
\hline
\end{tabular}

The mutual interaction of two different variables was taken into consideration in the study. As the structural footprint area decreased, the structure became more rigid. Consequently, the period value increased as the base area increased and seismic capacity decreased. As the number of floors increases, the period value increases, the stiffness value and seismic capacity decrease. The increase in the floor area and number of floors caused the structure to be less rigid. The total construction area increased since the increase of these two values, the approximate cost of the building also increased.

Cost comparisons were made only according to the total constructional area. It is obvious that the difference will be greater with the addition of other costs other than electricity, machinery and construction.

\section{Conclusions}

In structural analysis, the structural dimensions and the number of floors ensue as important factors. The structural dimensions and the total number of floors in the structure can take different values due to different reasons. Within the scope of this study, considering the number of floors and changes in structural dimensions, two different structural analyses were performed. The comparison of the values obtained as a result of 
the analyses is given in the study. In this study, level of change in the structure cost calculations of these two variables was also calculated.

In the study, it was seen that as the footprints and numbers of floors of structure increased, period values increased, too. Period values increased approximately equal in terms of change of footprints for all different numbers of floors. This also applies to the number of floors. The period value increased by $5 \%$ for each footprint change, while the period value increased by $19 \%$ for each increase of the number of floors. As the footprints and number of floors decreased, the cumulative mass participation percentages obtained in both $\mathrm{X}$ and $Y$ directions increased.

Among the results of the analysis used in the study, the smallest percentages of change were obtained at the base shear force. As the number of floors and footprints of the structure increased, the base shear forces decreased. One of the parameters obtained as a result of the analysis is the stiffness values. Both the elastic and effective stiffness values decreased naturally with the increase in the number of floors and the footprints. The percentages of stiffness change in increase of both number of floors and footprints were equal.

As a result of the analyses, the greatest percentages of change were observed at the target displacements predicted for the structure. Target displacement values for the settlement at the moment of flow (dy), non-collapsing (NC), severe damage (SD) and damage limitation (DL) increased depending on the footprints and number of floors. The increase in target displacements in terms of performance criteria reveals the direct relationship between the damage occurring in the earthquake and the number of floors.

Only construction costs were considered in the cost calculations. As the footprints and the number of floors increased, the building cost also increased. Cost increased by $20 \%$ for each increase in the number of the floors. As the footprints increased, the cost change occurred as much as the percentage of footprints changes. However, in the study, while the cost calculations were made, no cost calculations were made for electricity, machinery and similar works.

The importance of structural dimensions and number of floors were mentioned within the scope of the study. Unnecessary increase in dimensions and number of floors adversely affects both cost and structural analysis.

In addition to these parameters used in this study, models in which plan shape, element size and layout are taken into consideration can be developed. The height of the floors, several number of floors, the local soil conditions, the importance of the building and the seismicity conditions of the region where the building will be built will also change the structural analysis and cost values. The increase in the circumference in the buildings increases the facade area in the models of the same height, which also affects the facade insulation and exterior wall costs, which are the secondary construction costs. Construction cost has been calculated approximately. Using the unit prices for detailed cost analysis results will make the results more valuable.

\section{References}

[1] Ferraioli, M. (2016). Dynamic increase factor for pushdown analysis of seismically designed steel moment-resisting frames. International Journal of Steel Structures, 16(3), 857-875. https://doi.org/10.1007/s13296-015-0056-6 
[2] Işık, E. 2016. Consistency of the rapid assessment method for reinforced concrete buildings. Earthquakes and Structures, 11(5), 873-885. https://doi.org/10.12989/eas.2016.11.5.873

[3] Yakut, A. 2004. Preliminary seismic performance assessment procedure for existing RC buildings. Engineering $\quad$ Structures, 26(10), 1447-1461. https://doi.org/10.1016/j.engstruct.2004.05.011

[4] Šipoš, T. K., Hadzima-Nyarko, M. 2017. Rapid seismic risk assessment. International $\begin{array}{llll}\text { Journal of Disaster Risk Reduction, 24, 348-360. } & \text {. }\end{array}$ https://doi.org/10.1016/j.ijdrr.2017.06.025

[5] Hadzima-Nyarko, M., KalmanSipos, T. 2017. Insights from existing earthquake loss assessment research in Croatia. Earthquakes and Structures, 13(4), 365-375.

[6] Sucuoğlu, H. 2007. A screening procedure for seismic risk assessment in urban building stocks. Sixth National Conference on Earthquake Engineering, Istanbul, Turkey. https://doi.org/10.1193/1.2720931

[7] Şengezer, B.S. 1999. The damage distribution during March 13, 1992 Erzincan earthquake. YT U. Press Release Center, 13.

[8] Özdemir, M., Işık, E., Ülker, M. 2016. Performance evaluation of reinforced concrete buildings with different story numbers. BEU Journal of Science, 5(2), 183-190.

[9] Korkmaz, K.A., Düzgün, M. 2006. Statik artımsal itme analizinde kullanılan yük dağılımlarının değerlendirilmesi. Teknik Dergi, 17(82), 3873-3878.

[10] Sezer, F., Gençoğlu, M.,Celep, Z. 2007. Betonarme binaların deprem güvenliğinin değerlendirilmesinde deprem yönetmeliği 2007 de kurallarına örnekle kıyaslamalı bir bakıș. Altıncı Ulusal Deprem Mühendisliği Konferansı, İstanbul, Turkey.

[11] İlerisoy, Z.Y., Tuna, M.E. 201). Effects of plane dimensions and number of storeys on the cost of rectangular-plane buildings constructed with tunnel Form Megaron, 13(4), 559-568.

[12] Safiki, A., Solikin, M., Sahid, M.N. 2015. Cost implications of building design plans: a literature review analysis, The 2ndInternational Conference on Engineering Technology and Industrial Application (ICETEA-2015), Indonesia.

[13] Saidu, İ., Alumbugu, P.O., Abdulazeez, A., Ola-Awo, W.A., 2015. Assessment of the effect of plan shapes on cost of institutional buildings in Nigeria, International Refereed Journal of Engineering and Science (IRJES), 4(3), 39-50.

[14] Ferry, D.J., Brandon P.S. 2007. Cost planning of building, 9th Edition, Oxford: WileyBlackwell.

[15] Tregenza P. 1972. Association between building height and cost. Architects Journal Information Library, 11,1031-1032.

[16] Çıracı, M. 1996. Konutlarda maliyet tahmini için bir model, T.C. Başbakanlık Toplu Konut İdaresi Başkanlığı, Konut Araștırma Dizisi-6, Ankara.

[17] Türkel, E.B., Ergen, E. 2016. Tünel kalıp sistemi kullanılan betonarme yüksek yapılarda, yükseklik ve kat alanı ile maliyet arasındaki ilişki". Pamukkale Üniversitesi Mühendislik Bilimleri Dergisi, 22(6), 418-426.

[18] Antoniou, S., Pinho, R. 2003. Seismostruct - Seismic Analysis program by Seismosoft. Technical manual and user manual.

[19] Kutanis, M., Boru, E. O., Işık, E. 2017. Alternative instrumentation schemes for the structural identification of the reinforced concrete field test structure by ambient vibration measurements. KSCE Journal of Civil Engineering, 21(5), 1793-1801. https://doi.org/10.1007/s12205-016-0758-0

[20] SeismoStruct v6.5 2013. A computer program for static and dynamic nonlinear analysis of framed structures. Seismosoft. 
[21] Estêvão, J. M., Oliveira, C. S. 2015. A new analysis method for structural failure evaluation. Engineering Failure Analysis, 56, 573-584. https://doi.org/10.1016/j.engfailanal.2014.08.009

[22] Ademovic, N., Hrasnica, M., Oliveira, D.V. 2013. Pushover analysis and failure pattern of a typical masonry residential building in Bosnia and Herzegovina. Engineering Structures, 50, 13-29. https://doi.org/10.1016/j.engstruct.2012.11.031

[23] Chopra, A.K., Goel, R.K. 2002. A modal pushover analysis procedure for estimating seismic demands for buildings. Earthquake Engineering \& Structural Dynamics, 31(3), 561-582. https://doi.org/10.1002/eqe.144

[24] Inel, M., Meral, E. 2016. Seismic performance of RC buildings subjected to past earthquakes in Turkey. Earthquakes and Structures, 11(3), 483-503. https://doi.org/10.12989/eas.2016.11.3.483

[25] Işık, E., Özdemir, M. 2017. Performance based assessment of steel frame structures by different material models. International Journal of Steel Structures, 17(3), 1021-1031. https://doi.org/10.1007/s13296-017-9013-x

[26] Menegotto, M. 1973. Method of analysis for cyclically loaded RC plane frames including changes in geometry and non-elastic behavior of elements under combined normal force and bending. In Proc. of IABSE symposium on resistance and ultimate deformability of structures acted on by well-defined repeated loads (pp.15-22).

[27] Bosco, M., Ferrara, E., Ghersi, A., Marino, E. M., Rossi, P. P. 2016. Improvement of the model proposed by Menegotto and Pinto for steel. Engineering Structures, 124, 442456. https://doi.org/10.1016/i.engstruct.2016.06.037

[28] http://www.resmigazete.gov.tr/eskiler/2019/03/20190316-12.htm, (Last accessed August 2019) 